\title{
特異值分解による運動動作の特徵獲得 †
}

\author{
姜 銀来 $* 1 \cdot$ 林 勲 $* 2$ ・王 碩玉 $* 1$
}

近年, 身体の動作に関与した様々な研究が行われている.川人は, 身体を一つのモデルと仮定し, フィー ドバックとフィードフォワード制御からなる脳と身体間の閉回路で身体内部モデルを構成し，身体動作の しなやかさを説明している. 本論文では, 内部モデルを入出力データから得られる一つの関数モデルとし て捉え，身体に装着した各種センサーから身体動作の時系列データを検出し，特異值分解を用いてその動 作の特徴を抽出するモデルを提案する。ここでは,この内部モデルによって得られた知識を身体知と呼ぶ. 具体的には, 左特異ベクトルを用いた類似度と評価值から 2 種類の識別モデルを構成し，手招きのジェス チャーを識別した。また, 特異值によって構成される 3 次元の超平面から歩行動作の識別を行った。最後 に，本論文での特異值分解を用いた動作解析手法の特徴と意義について，考察を行った。

キーワード：特異值分解, 身体知, 手招き動作, 歩行動作, 動作分析

\section{1 . はじめに}

近年，医療，スポーツ，芸術などの分野で身体の動 作に関与した研究が盛んに行われている $[1]-[9]$ 。こ の身体動作の研究には, 脳生理学や身体構造学からの 観点だけでなく，身体を一つのモデルと仮定し，その 振る舞いから身体構造を同定する研究がある。川人 [10]はこのモデルを内部モデルと呼び, 脳神経と制御 モデルの融合モデルとして提案している，内部モデル は，脳と身体間のフィードバック制御とフィードフォ ワード制御の閉回路からなり，相互間の脳信号がなめ らかな身体動作の制御を可能にする。一方, Miallら [11]は，時間遅れのないスミス型フィードバック制御 系によって，脳から身体へのフィードフォワードモデ ルを提案している。

しかし, 本論文では, 内部モデルを脳神経学や制御 学から捉えるのではなく, 入出力データから得られる 一つの関数モデルとして捉え, その入出力データの差 異に対するモデルの振る舞いに焦点をあてる。眓 1 に 本研究の研究概念を示す. 内部モデルは入出力データ から同定され, 入力に対する出力の感度解析が可能と なる。また，同定されたモデルの構造を知識で表現す ることによって, その振る舞いを解析することができ る.ここでは, この内部モデルによって得られた知識 を身体知と呼ぶ。ただし，本論文では，身体知研究の

\footnotetext{
$\dagger$ Acquisition of Motion Features by Singular Value Decomposition Yinlai JIANG, Isao HAYASHI and Shuoyu WANG

*1 高知工科大学 システム工学群

School of Systems Engineering, Kochi University of Technology $* 2$ 関西大学大学院 総合情報学研究科

Graduate School of Informatics, Kansai University
}

中でも，ジェスチャー解析や歩行動作に特化したモデ ルのみを取り扱うこととし，動作の時系列データか ら，特異值分解[12]を用いた提案モデルにより内部モ デルを同定する [13]-[16]。具体的には，身体に装着 した各種のセンサーから身体動作の時系列データを検 出し, それらの時系列データから特異值分解を用いた 提案モデルで動作を識別する。

従来から, ジェスチャー動作や歩行動作などの身体 動作の解析には, フーリエ変換, 判別分析, 主成分分 析, サポートベクタマシンなど, 多くの手法が提案さ れている. Mitraら [17]は，ジェスチャー動作の研究 調査を行い，隠れマルコフモデルを用いたジェス チャー動作の同定法を提案している. Iwaiら [18]は， カラーグローブによって検出された単眼イメージから， ジェスチャーを認識するCAD手法を提案している. Lamarら [19]は, 時系列データに対応するニューラル ネットワークTemporal-CombNET(T-Comb NET)を 提案している.Jerdeら[20]は, 計測用グローブを用 いて，手書き操作を行う際の関節位置を推定し，その

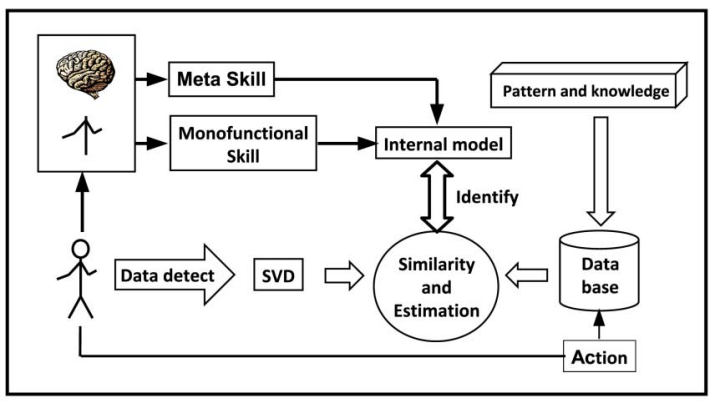

図 1 Proposed Model 
位置から主成分分析により動作の識別を行っている。 Williamsonら [21]は, 加速度計測の歩行データから， 機械学習により足取りの分析を行っている. Jakobsen ら [22]は，相関係数を用いた誤差最小法により，リハ ビリテーションにおける膝関節可動域の評価を行って いる。 その他にも多くの手法が提案されている $[23]-$ [28]. しかし, 隠机マルコフモデルはデータ数が多い 場合や不連続データの場合には, 認識精度が良くない との報告がある。また，ニューラルネットワークの精 度は時系列データの長さに依存する。ささらに, 主成分 分析は, 平均值からの偏差によるデータ行列を用い, 共分散行列の最適化問題をラグランジュ乗数法で解く が, このデータ行列のデータ数が不足する場合には寄 与率が低下し, 認識率が低下する。

最近, 特異值分解を用いた動作解析法が提案されて いる [29]-[31]. 特異值分解は, 時系列データからハ ンケル行列を構成し, 特異值, 左特異ベクトル, 右特 異ベクトルに分解する. 左特異ベクトルが時系列デー タの特徵を抽出し, 特異值が左特異べクトルの重みを 表現していることから, 特異值の高い左特異べクトル はその動作の時系列データの特徴を良く表現する。時 系列の観測データのデータ長が異なる場合に, 正規化 によりそのデータ長の違いを吸収する方法も考えられ る。しかし, 特異值分解は, データを重複してハンケ ル行列を構成するため, データ長に依存せず，時系列 データの個数に対する制約が低いという特徴がある.

主成分分析と特異值分解との違いは, 特異值分解が データの重複を許容するハンケル行列を観測データと するのに対して, 主成分分析は通常各観測データの平 均值からの偏差による観測データ行列を対象とする.

一方, 主成分分析の第 $i$ 主成分の結合係数は, データ 行列の $i$ 番目に大きな特異值 $\alpha$ に対応する右特異べ クトルとして与えられる $[32,33]$.

本論文では，この特異值分解の左特異べクトルを用 いた 2 種類の識別手法を提案し, 手招き動作 (ジェス チャー)を解析する。 また, 特異值を用いた可視化手 法を提案し，歩行動作を識別する。なお，ここでの目 的は, 単なる動作判別を行うことではなく, 動作デー タから得られる知識の表現方法にある。したがって, 例えば, 手招き動作の解析では, 動作開始点を知るこ とにより手招きの種類を判別することは比較的容易で あるが, この観点からではなく識別率と動作表現によ る類似性の両観点から議論することとする。具体的に は, 手招き動作では, 高速度カメラにより 5 種類の ジェスチャーを測定し，2 種類の識別モデルにより識 別精度を検分した。 また, 歩行動作では, 装着器具に より被験者の歩行に一定の拘束を施し，特異值によっ
て構成される 3 次元での超平面によって歩行困難の識 別を行った。この超平面は, 理学療法士や医師が, 患 者の歩行の回復状態を判断する可視化ツールとして利 用できる. 最後に, 特異值分解を用いた本手法の特徴 と意義について考察を行った。

\section{2. 特異值分解}

いま，身体に装着した $w$ 個の計測点 $\left(P_{1}, P_{2}, \cdots, P_{w}\right)$ で動作 $G$ を観測する。この計測点 $P_{i}$ での時系列デー 夕を $\tau^{i, G}=\left(X^{i, G}, Y^{i, G}, Z^{i, G}\right)$ と表す。罒 2 に示すよう に, 特異值分解では, 時系列データ $\tau^{i, G}$ から $m$ 個の 離散データを $n$ 個の重複を許して抽出し, $n \times m$ の八 ンケル行列 $M_{X}^{i, G}, M_{Y}^{i, G}, M_{Z}^{i, G}$ を構成する.

$M_{X}^{i, G}=\left(X_{1}^{i, G}, X_{2}^{i, G}, \cdots, X_{n}^{i, G}\right)^{T}$

$M_{Y}^{i, G}=\left(Y_{1}^{i, G}, Y_{2}^{i, G}, \cdots, Y_{n}^{i, G}\right)^{T}$

$M_{Z}^{i, G}=\left(Z_{1}^{i, G}, Z_{2}^{i, G}, \cdots, Z_{n}^{i, G}\right)^{T}$

ここで, $X_{p}^{i, G}=\left(x_{p, 1}^{i, G}, x_{p, 2}^{i, G}, \cdots, x_{p, m}^{i, G}\right), p=1,2, \cdots$, $n$ であり, $x$ は $X$ 軸の時系列データである. $y$ と $z$ に 関しても同様である。

説明を簡単にするため, ハンケル行列を $M_{k}^{i, G}, k=$ $\{X, Y, Z\}$ で表現する。 ハンケル行列 $M_{k}^{i, G}$ は次のよ うに分解できる。

$M_{k}^{i, G}=U_{k}^{i, G} \Sigma_{k}^{i, G}\left\{V_{k}^{i, G}\right\}^{T}$

ただし,$U_{k}^{i, G}=\left(u_{1, k}^{i, G}, u_{2, k}^{i, G}, \cdots, u_{m, k}^{i, G}\right)$ は $m \times m$ のユニ タリ行列であり, $\left\{V_{k}^{i, G}\right\}^{T}=\left(v_{1, k}^{i, G}, v_{2, k}^{i, G}, \cdots, v_{n, k}^{i, G}\right)^{T}$ は $n \times n$ のユニタリ行列である。 また, $\sum_{k}^{i, G}$ は $m \times n$ で, 対角成分以外は零, 対角成分は非負となる行列である. $\sum_{k}^{i, G}$ の対角要素は特異值を示し, $U_{k}^{i, G}$ を左特異べ

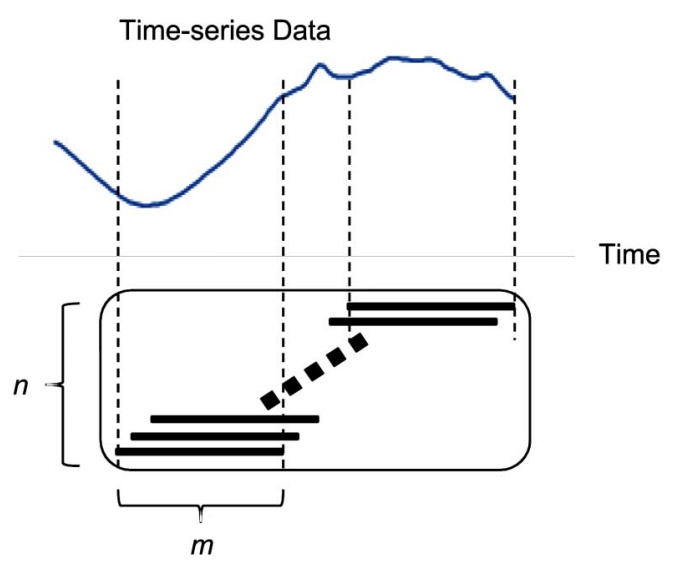

図 2 Design of Matrix $M_{X}^{i, G}$ 
クトル,$V_{k}^{i, G}$ を右特異べクトルと呼ぶ。いま，左特異 ベクトルの個数を $l$ とし，第 $j$ 番目の左特異べクトル の要素数を $q$ とする. 特異值の大きさの順に左特異べ クトルを並べると, 特異值と左特異べクトルの組は, $\left(\left(\sigma_{1, k}^{i, G}, u_{1, k}^{i, G}\right),\left(\sigma_{2, k}^{i, G}, u_{2, k}^{i, G}\right), \cdots,\left(\sigma_{l, k}^{i, G}, u_{l, k}^{i, G}\right)\right)$, for $u_{j, k}^{i, G}=$ $\left(\hat{u}_{1 j, k}^{i, G}, \hat{u}_{2 j, k}^{i, G}, \cdots, \hat{u}_{h j, k}^{i, G}, \cdots, \hat{u}_{q j, k}^{i, G}\right)$ と表される. ただし, $\hat{u}_{h j, k}^{i, G}$ は, 第 $j$ 番目の左特異べクトル $u_{j, k}^{i, G}$ の第 $h$ 番目 の要素である. 左特異べクトル $U_{k}^{i, G}$ は, ハンケル行 列 $M_{k}^{i, G}$ の特徴を示し, 特異值 $\Sigma_{k}^{i, G}$ は, $M_{k}^{i, G}$ に対する 左特異べクトルの影響の大きさを示している．特異值 分解は, 左特異ベクトルが時系列データの特徴を抽出 し, 特異值が左特異べクトルの重みを表現しているこ とから，特異值の高い左特異べクトルはその動作の時 系列データの特徴を良く表現する。しかし，その一方 で，ハンケル行列を構成する際，データ長 $m$ や左特 異值べクトルの個数 $l$ を決定する方法がなく, パラ メータ調整は今後の課題といえる。なお，ここでは， 全時系列データは, 動作の特徴を抽出するための学習 用データ $\tau_{T R D}^{i, G}$ (TrainingData:TRD) と学習した結果を 評価するための評価用データ $\tau_{C H D}^{i, G}$ (CheckingData: CHD)に分割される.

\section{3．左特異ベクトルを用いた動作認識}

動作計測の設備として，(株)ライブラリ社製の高速 度カメラ GE $60 / \mathrm{W}, 60 \mathrm{~Hz}$ とそのデータ処理ソフト ウェア $($ Move-tr/3D) を用いた。被験者は20代の男性 2 名 (TWとST)である。動作座標を取得するため，被 験者の指と手首に 5 つのマーカーを装着した。 $P_{1}$ ：右 手の親指先端部, $P_{2}$ : 右手の中指先端部, $P_{3}$ : 右手の 小指先端部, $P_{4}$ : 右手の手首の親指側, $P_{5}$ : 右手の手 首の小指側である。動作は $50 \mathrm{~cm} \times 50 \mathrm{~cm} \times 50 \mathrm{~cm}$ の立方 体の内部で行う。困 3 に実験風景と計測座標を示す. 本来なら，自然な動作を測定するためには，ジェス

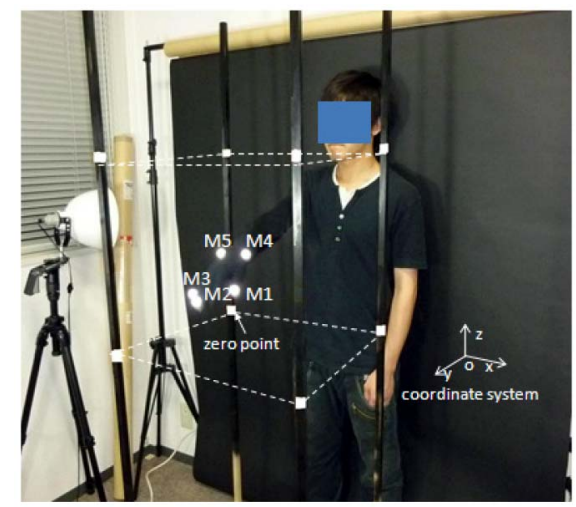

図 3 Experiment Environment for Gesture
チャーの大きさに依存して観測空間の大きさを変化さ せるか，ジェスチャーの大きさを観測空間に依存しな いように動作データを正規化すべきである。しかし， 本実験では, 観測空間は, $50 \mathrm{~cm} \times 50 \mathrm{~cm} \times 50 \mathrm{~cm}$ の立 方体の内部に限定している。この動作データの正規化 は重要な実験因子であると考えられるので, この問題 は今後の課題としたい.

計測では， 5 種類の動作命令として，手招き $\mathrm{CH}$ (Come Here), 追払いGA (Go Away), 右誘導GR(Go Right), 左誘導 GL (Go Left), 沈静化 CD (Calm Down）を選択して実測した。ここでは，各被験者に 対して同じ動作を 9 回測定し，最初の 5 回をTRDに 設定し，残りの 4 回をCHDに設定した。

被験者TWの $P_{2}$ で計測された時系列データを図 4 に 示す. $\mathrm{GA}, \mathrm{CH}, \mathrm{CD}$ の動作は上下 $(Z$ 軸 $)$ 方向と前後 (Y軸) 方向に変化が大きく, GR, GLの動作は左右 $(\mathrm{X}$ 軸)方向に変化が大きいことがわかる。また， 5 種類 の動作を図 5 に示す。（a） に 5 種類の動作命令を示 し, 被験者はこの 5 種類の動作命令に対して連続動作 を行う。なお, 各動作の開始点と終了点は異なるが, 厳密な動作認識のモデルを求めるよりも, 特異值分解 による動作要素の抽出が目的であるので, 開始点と終 了点はそのままとした。また，手招き $\mathrm{CH}$ の分解困を (b)に示す. 1 回の手招き $\mathrm{CH}$ 動作を 9 枚の静止画で 表している。
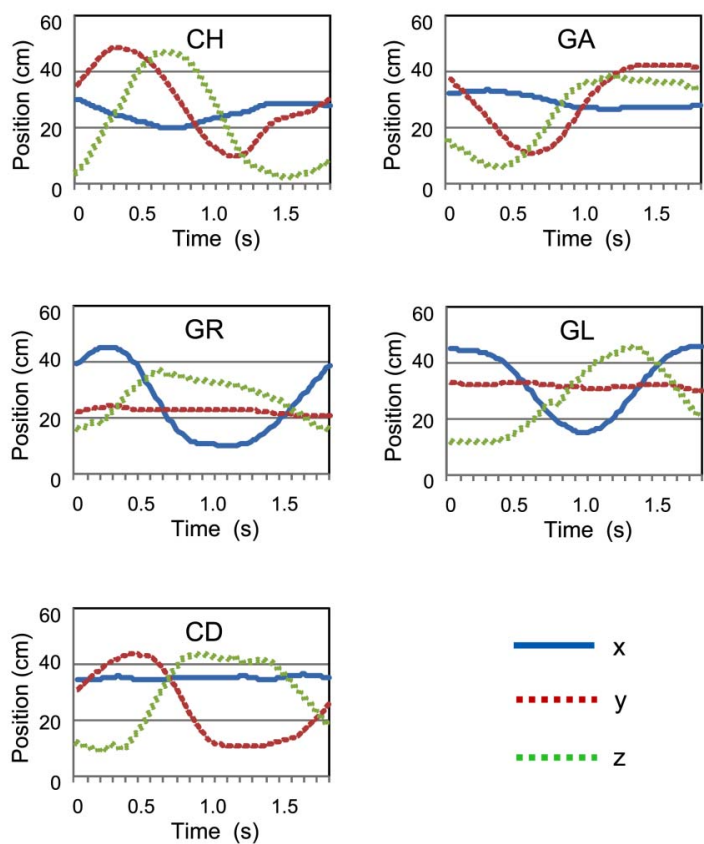

図 4 Time- series Data of Gestures 


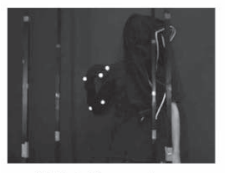

$\mathrm{CH}$ : Come here

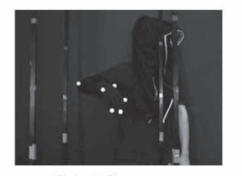

GA : Go away

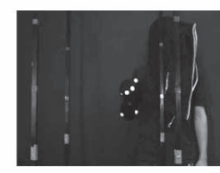

CD : Calm down

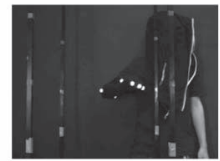

GR : Go right

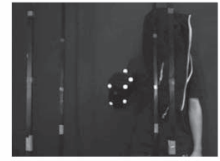

GL : Go left (a) Five Kinds of Hand Gestures
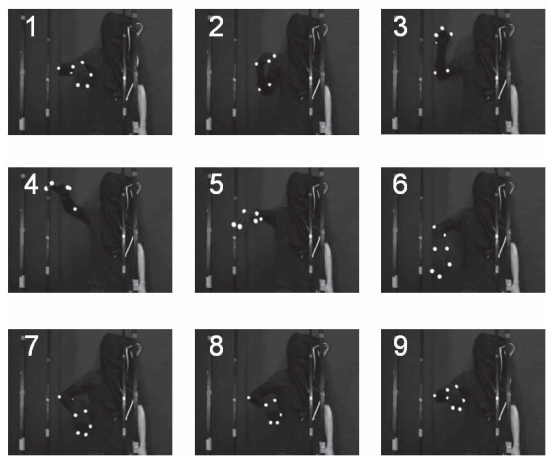

(b) Motion of Hand Gestures CH

図 5 Hand Gestures

\section{1 動作距離の類似性による手法}

動作距離の類似性による手法では，動作を識別する ために，TRDとCHD間で左特異べクトルを用いて定 義される次の 3 種類の類似度を定義する。

$$
\begin{aligned}
S_{1} & : r_{i}\left(U_{T R D}^{i, G}, U_{C H D}^{i}\right) \\
& =\frac{1}{3 l q} \sum_{k=1}^{3} \sum_{j=1}^{l}\left|\sum_{h=1}^{q} \hat{u}_{h j, k, T R D}^{i, G}-\sum_{h=1}^{q} \hat{u}_{h j, k, C H D}^{i}\right|
\end{aligned}
$$$$
S_{2}: r_{i}\left(U_{T R D}^{i, G}, U_{C H D}^{i}\right)
$$$$
=\frac{1}{3 l q} \sum_{k=1}^{3} \sum_{j=1}^{l} \sum_{h=1}^{q}\left|\hat{u}_{h j, k, T R D}^{i, G}-\hat{u}_{h j, k, C H D}^{i}\right|
$$

$$
\begin{aligned}
S_{3} & : r_{i}\left(U_{T R D}^{i, G}, U_{C H D}^{i}\right) \\
& =\frac{1}{3 l q} \sum_{k=1}^{3} \sqrt{\sum_{j=1}^{l} \sum_{h=1}^{q}\left(\hat{u}_{h j, k, T R D}^{i, G}-\hat{u}_{h j, k, C H D}^{i}\right)^{2}}
\end{aligned}
$$

ここで, $U_{X, T R D}^{i, G}=\left(u_{1, X, T R D}^{i, G}, u_{2, X, T R D}^{i, G}, \cdots, u_{l, X, T R D}^{i, G}\right)$, for $u_{j, X, T R D}^{i, G}=\left(\hat{u}_{1 j, X, T R D}^{i, G}, \hat{u}_{2 j, X, T R D}^{i, G}, \cdots, \hat{u}_{h j, X, T R D}^{i, G}, \cdots\right.$, $\left.\hat{u}_{q j, X, T R D}^{i, G}\right)$ は, TRDの左特異ベクトルであり, $U_{X, C H D}^{i}=$ $\left(u_{1, X, C H D}^{i}, u_{2, X, C H D}^{i}, \cdots, u_{l, X, C H D}^{i}\right)$, for $u_{j, X, C H D}^{i}=$
表 1 Recognition of Gestures

\begin{tabular}{c|c|c|c}
\hline & $\begin{array}{c}\text { Similarity } \\
\left(S_{1}\right)\end{array}$ & $\begin{array}{c}\text { Similarity } \\
\left(S_{2}\right)\end{array}$ & $\begin{array}{c}\text { Similarity } \\
\left(S_{3}\right)\end{array}$ \\
\hline $\begin{array}{c}\text { Estimation } \\
\left(E_{1}\right)\end{array}$ & 70.0 & 90.0 & 80.0 \\
\hline $\begin{array}{c}\text { Estimation } \\
\left(E_{2}\right)\end{array}$ & 60.0 & 80.0 & 80.0 \\
\hline
\end{tabular}

表 2 Comparison of Markers by Gesture Distances

\begin{tabular}{c|c|c|c|c|c}
\hline Sub./Ges. & \multicolumn{5}{|c}{ Markers } \\
\hline TW & $P_{1}$ & $P_{2}$ & $P_{3}$ & $P_{4}$ & $P_{5}$ \\
\hline $\mathrm{CH}$ & $4 / \mathrm{GA}$ & $4 / \mathrm{GA}$ & $4 / \mathrm{CD}$ & $4 / \mathrm{GA}$ & $4 / \mathrm{GA}$ \\
$\mathrm{GA}$ & $8 / \mathrm{GA}$ & $9 / \mathrm{GA}$ & $9 / \mathrm{GA}$ & $8 / \mathrm{GA}$ & $8 / \mathrm{GA}$ \\
$\mathrm{GR}$ & $7 / \mathrm{GR}$ & $8 / \mathrm{GR}$ & $8 / \mathrm{GR}$ & $6 / \mathrm{GR}$ & $5 / \mathrm{GR}^{*}$ \\
$\mathrm{GL}$ & $5 / \mathrm{GL}$ & $4 / \mathrm{GL}$ & $4 / \mathrm{GL}$ & $5 / \mathrm{GL}$ & $5 / \mathrm{GL}$ \\
$\mathrm{CD}$ & $6 / \mathrm{CD}$ & $5 / \mathrm{GA}$ & $5 / \mathrm{GA}$ & $7 / \mathrm{CD}$ & $8 / \mathrm{CD}$ \\
\hline $\mathrm{ST}$ & $P_{1}$ & $P_{2}$ & $P_{3}$ & $P_{4}$ & $P_{5}$ \\
\hline $\mathrm{CH}$ & $8 / \mathrm{CH}$ & $9 / \mathrm{CH}$ & $11 / \mathrm{CH}$ & $9 / \mathrm{CH}$ & $7 / \mathrm{CH}$ \\
$\mathrm{GA}$ & $7 / \mathrm{GA}$ & $9 / \mathrm{GA}$ & $9 / \mathrm{GA}$ & $9 / \mathrm{GA}$ & $5 / \mathrm{CD}$ \\
$\mathrm{GR}$ & $9 / \mathrm{GR}$ & $10 / \mathrm{GR}$ & $11 / \mathrm{GR}$ & $6 / \mathrm{GR}$ & $9 / \mathrm{GR}$ \\
$\mathrm{GL}$ & $7 / \mathrm{GL}$ & $8 / \mathrm{GL}$ & $10 / \mathrm{GL}$ & $5 / \mathrm{GL}$ & $8 / \mathrm{GL}$ \\
$\mathrm{CD}$ & $4 / \mathrm{CD}$ & $5 / \mathrm{GL}$ & $5 / \mathrm{GL}$ & $5 / \mathrm{CD}$ & $6 / \mathrm{CD}$ \\
\hline Accuracy & & & & & \\
$(\%)$ & 93.85 & 80.28 & 81.58 & 93.75 & 86.15 \\
\hline
\end{tabular}

$\left(\hat{u}_{1 j, X, C H D}^{i}, \hat{u}_{2 j, X, C H D}^{i}, \cdots, \hat{u}_{h j, X, C H D}^{i}, \cdots, \hat{u}_{q j, X, C H D}^{i}\right)$ は, CHDの左特異べクトルである。

式(5) は左特異べクトルの要素全ての和を求め, そ の差の絶対值を類似度とする。式(6) は左特異べクト ルの要素で同順位の差を求め, その和の絶対值を類似 度とする. 式(7) は左特異ベクトルを多次元上の座標 と見なし，2点間距離を類似度とする。

全体の類似度は次の 2 種類の評価指標で計算される。

$$
\begin{aligned}
& E_{1}: G^{*}=\left\{G_{f} \mid \max _{f} \sum_{i=1}^{w} n\left(G_{f}^{i}\right),\right. \\
& \text { for } \left.G_{f}^{i}=\left\{G_{f} \mid \min _{f} r_{i}\left(U_{T R D}^{i, G_{f}}, U_{C H D}^{i}\right)\right\}\right\} \\
& E_{2}: G^{*}=\left\{G_{f} \mid \min _{f} \sum_{i=1}^{w} r_{i}\left(U_{T R D}^{i, G_{f}}, U_{C H D}^{i}\right)\right\}
\end{aligned}
$$

ここで, $G_{f}$ は $f$ 番目のジェスチャーであり,$n\left(G_{f}^{i}\right)$ は計数関数である.

評価 $E_{1}$ は各マーカごとに類似度が最小となるジェ スチャーを判別し, 全マーカで類似度のカウント個数 が最大のジェスチャーを推定結果のジェスチャー $G^{*}$ とする。評価 $E_{2}$ は全マーカで類似度の和の最小值を 持つジェスチャーを推定結果 $G^{*}$ とする.

これらの類似度と評価指標の有用性を議論するた め, ジェスチャー実験を行った。 ハンケル行列の大き 
さは，被験者TWとSTの動作の時間的長さから $m=$ $125, n=5$ とした。 また，他のパラメータは， $q=125$, $l=1, w=5$ とした。計測の結果を表 1 に示す. 結果 から, 類似度 $S_{1}$ と $S_{2}$ の認識率は比較的高いことが わかる. 特に, 類似度 $S_{2}$ と評価 $E_{1}$ の組み合わせが 最も良い結果を示しており，認識率も $90.0 \%$ と高い. したがって, この類似度 $S_{2}$ と評価 $E_{1}$ の組み合わせ が，ジェスチャーの識別に有用であるといえる.

類似度 $S_{2}$ と評価 $E_{1}$ の組み合わせに基づいて算出 した各マーカのジェスチャーの認識結果を表 2 に示 す。表では，ジェスチャーごとに各マーカで認識され たジェスチャー種別とその回数を $a / b$ で表している. ここで， $b$ は認識されたジェスチャーを表し， $a$ はそ の回数を表す。また,$b^{*}$ は $b$ 以外にも他に認識され たジェスチャーが存在することを示す。第 1 マーカ $P_{1}$ での認識率が $93.85 \%$ と高く, 最も重要なマーカと して抽出されている。第 1 マーカ $P_{1}$ は右手の親指先 端部を示しているので, このことから，動作を認識す る際には親指の動作が最も重要な意味を持つことがわ かる。

\section{2 動作べクトルの類似性による手法}

動作べクトルの類似性による手法では, 動作を識別 するために, 式(1)のTRDの時系列データ $M_{X}^{i, G}$ の一部 をCHDと入れ替える。いま，TRDの第 $p$ 番目のデー タ $X_{p}^{i, G}$ をCHDの $X_{C H D}^{i}$ と入れ替えることを仮定する.

$M_{X, C H D}^{i}=\left(X_{1}^{i, G}, \cdots, X_{p-1}^{i, G}, X_{C H D}^{i}, X_{p+1}^{i, G}, \cdots, X_{n}^{i, G}\right)^{T}$

この場合, もし,$X_{p}^{i, G}$ と $X_{C H D}^{i}$ が同じ傾向のデータ であれば, $X_{C H D}^{i}$ が組み入れられた $M_{X, C H D}^{i}$ の左特異 ベクトルは元の $M_{X}^{i, G}$ の左特異べクトルと類似する. そこで, $M_{X}^{i, G}$ の左特異べクトル $U_{T R D}^{i, G}$ と $M_{X, C H D}^{i}$ の左 特異べクトル $U_{C H D}^{i}$ の類似度を次のように定義する.

$$
\begin{aligned}
S_{4} & : r_{i}\left(U_{T R D}^{i, G}, U_{C H D}^{i}\right) \\
& =\frac{1}{3 l q} \sum_{k=1}^{3} \sum_{j=1}^{l}\left|\sum_{h=1}^{q} \hat{u}_{h j, k, T R D}^{i, G}-\sum_{h=1}^{q} \hat{u}_{h j, k, C H D}^{i}\right|
\end{aligned}
$$

$$
\begin{aligned}
S_{5} & : r_{i}\left(U_{T R D}^{i, G}, U_{C H D}^{i}\right) \\
& =\frac{1}{3 l q} \sum_{k=1}^{3} \sum_{j=1}^{l} \sum_{h=1}^{q}\left|\hat{u}_{h j, k, T R D}^{i, G}-\hat{u}_{h j, k, C H D}^{i}\right|
\end{aligned}
$$

$$
\begin{aligned}
S_{6} & : r_{i}\left(U_{T R D}^{i, G}, U_{C H D}^{i}\right) \\
& =\frac{1}{3 l q} \sum_{k=1}^{3} \sqrt{\sum_{j=1}^{l} \sum_{h=1}^{q}\left(\hat{u}_{h j, k, T R D}^{i, G}-\hat{u}_{h j, k, C H D}^{i}\right)^{2}}
\end{aligned}
$$

ただし, ここでは, $X_{C H D}^{i}$ の位置は, 時系列データの 最後, すなわち, 式(10)の $n$ 番目の $X_{n}^{i, G}$ とする.

全体の類似度は次の評価指標で計算される。

$E_{3}: G^{*}=\left\{G_{f} \mid \min _{f} \sum_{i=1}^{w} r_{i}\left(u_{T R D}^{i, G_{f}}, u_{C H D}^{i}\right)\right\}$

計測の結果を表 3 に示す. 結果から類似度 $S_{5}$ の認 識率が高いことがわかる. 類似度 $S_{5}$ は, 類似度 $S_{2}$ と 同様の類似指標であるので, 類似度 $S_{2}$ や類似度 $S_{5}$ の 計算方法はジェスチャーの識別に有用であるといえる.

動作距離の類似性による手法と同様に, 類似度 $S_{5}$ と評価 $E_{3}$ を用いて, 各マーカのジェスチャー認識を 調べた。表 4 に結果を示す. 同様に, 第 1 マーカ $P_{1}$ が最重要マーカとして抽出された。これらから, 第 1 マーカ $P_{1}$ が, 動作認識の最も重要な箇所であること がわかる。

最後に, 本手法と従来の動作解析手法とを比較し た。従来手法として, 相関係数と主成分分析を用い た。主成分分析では, 計測点 $P_{i}$ での動作 $G$ の時系列 データ $\tau^{i, G}=\left(X^{i, G}, Y^{i, G}, Z^{i, G}\right)$ に対して, 動作種別と $(X, Y, Z)$ の 3 方向からなる観測データを第 3 主成分 まで軸変換を行い, TRDとCHD間で比較した。主成 分分析を用いたクラスタリング手法(PCA Clustering) では, 各動作のクラスターの中心からの距離を用いて, また，主成分分析を用いた動作距離法(PCA Distance) では, 類似度 $S_{2}$ を用いて比較した。結果を表 5 に示 す. 動作距離法では，全てのマーカに対して，90.0\% と高い值を示しており, 各マーカの認識平均值でも 87.12\%の精度を得た。動作べクトル法では, 全ての マーカに対して, $80.0 \%$ と高い值を示し, 第 1 マーカ では93.94\%の精度を得た。

表 3 Results of Method for Similarity between Gesture Vectors

\begin{tabular}{c|c|c|c|c}
\hline Sub. & Ges. & $\begin{array}{c}\text { Similarity } \\
\left(S_{4}\right)\end{array}$ & $\begin{array}{c}\text { Similarity } \\
\left(S_{5}\right)\end{array}$ & $\begin{array}{c}\text { Similarity } \\
\left(S_{6}\right)\end{array}$ \\
\hline \multirow{5}{*}{ TW } & CH & 1 & 2 & 1 \\
& GA & 3 & 4 & 4 \\
& GR & 2 & 3 & 3 \\
& GL & 1 & 3 & 3 \\
& CD & 0 & 3 & 3 \\
\hline \multirow{5}{*}{ ST } & CH & 2 & 2 & 2 \\
& GA & 1 & 4 & 4 \\
& GR & 3 & 4 & 4 \\
& GL & 0 & 3 & 2 \\
\hline \multicolumn{2}{c|}{ Accuracy } & 0 & 4 & 4 \\
\multicolumn{2}{c|}{$(\%)$} & 30.3 & 80.0 & 75.0 \\
\hline
\end{tabular}


表 4 Comparison of Markers by Gesture Vectors

\begin{tabular}{c|c|c|c|c|c}
\hline Sub./Ges. & \multicolumn{5}{|c}{ Markers } \\
\hline TW & $P_{1}$ & $P_{2}$ & $P_{3}$ & $P_{4}$ & $P_{5}$ \\
\hline $\mathrm{CH}$ & $2 / \mathrm{GA}$ & $2 / \mathrm{GA}$ & $2 / \mathrm{GA}$ & $3 / \mathrm{GA}$ & $2 / \mathrm{GA}$ \\
$\mathrm{GA}$ & $4 / \mathrm{GA}$ & $4 / \mathrm{GA}$ & $2 / \mathrm{GA}^{*}$ & $4 / \mathrm{GA}$ & $4 / \mathrm{GA}$ \\
$\mathrm{GR}$ & $3 / \mathrm{GR}$ & $3 / \mathrm{GR}$ & $3 / \mathrm{GR}$ & $3 / \mathrm{GR}$ & $3 / \mathrm{GR}^{*}$ \\
$\mathrm{GL}$ & $3 / \mathrm{GL}$ & $3 / \mathrm{GL}$ & $3 / \mathrm{GL}$ & $3 / \mathrm{GL}$ & $3 / \mathrm{GL}$ \\
$\mathrm{CD}$ & $3 / \mathrm{CD}$ & $2 / \mathrm{GA}$ & $3 / \mathrm{GA}$ & $2 / \mathrm{CD}$ & $2 / \mathrm{CD}$ \\
\hline $\mathrm{ST}$ & $P_{1}$ & $P_{2}$ & $P_{3}$ & $P_{4}$ & $P_{5}$ \\
\hline $\mathrm{CH}$ & $2 / \mathrm{CH}^{*}$ & $2 / \mathrm{CH}^{*}$ & $2 / \mathrm{CH}^{*}$ & $2 / \mathrm{CH}^{*}$ & $2 / \mathrm{CH}^{*}$ \\
$\mathrm{GA}$ & $4 / \mathrm{GA}$ & $4 / \mathrm{GA}$ & $4 / \mathrm{GA}$ & $4 / \mathrm{GA}$ & $4 / \mathrm{CD}$ \\
$\mathrm{GR}$ & $4 / \mathrm{GR}$ & $4 / \mathrm{GR}$ & $4 / \mathrm{GR}$ & $3 / \mathrm{GR}$ & $3 / \mathrm{GL}$ \\
$\mathrm{GL}$ & $4 / \mathrm{GL}$ & $4 / \mathrm{GL}$ & $4 / \mathrm{GL}$ & $3 / \mathrm{GR}$ & $4 / \mathrm{GR}$ \\
$\mathrm{CD}$ & $4 / \mathrm{CD}$ & $4 / \mathrm{CD}$ & $4 / \mathrm{CD}$ & $3 / \mathrm{CD}$ & $4 / \mathrm{CD}$ \\
\hline Accuracy & & & & & \\
(\%) & 93.94 & 87.50 & 83.87 & 80.00 & 58.06 \\
\hline
\end{tabular}

表 5 Comparison of Methods

\begin{tabular}{c|c|c|c|c|c}
\hline & $\begin{array}{c}\text { Ges. } \\
\text { Markers }\end{array}$ & $\begin{array}{c}\text { Ges. } \\
\text { Dist. }\end{array}$ & $\begin{array}{c}\text { Corre. } \\
\text { Co. }\end{array}$ & $\begin{array}{c}\text { PCA } \\
\text { Clus. }\end{array}$ & $\begin{array}{c}\text { PCA } \\
\text { Dist. }\end{array}$ \\
\hline$P_{1}$ & 93.85 & 93.94 & 60.0 & 20.0 & 60.0 \\
$P_{2}$ & 80.28 & 87.5 & 80.0 & 40.0 & 80.0 \\
$P_{3}$ & 81.58 & 83.87 & 80.0 & 60.0 & 40.0 \\
$P_{4}$ & 93.75 & 80.0 & 80.0 & 40.0 & 40.0 \\
$P_{5}$ & 86.15 & 58.06 & 60.0 & 20.0 & 40.0 \\
\hline Average & 87.12 & 80.67 & 72.0 & 36.0 & 52.0 \\
\hline All & & & & & \\
Markers & 90.0 & 80.0 & 70.0 & 60.0 & 40.0 \\
\hline
\end{tabular}

一方, 相関係数による判別法では, 認識率は悪くは ないが，良いとも言えない。また，主成分分析を用い たクラスタリング手法, 主成分分析を用いた動作距離 法では，良い認識率が得られなかった。これらの考え られる原因として, 相関係数と主成分分析は, 時系列 データの長さに強く依存するので, TRDとCHDで データ長が異なる場合に, 良い認識率が得られなかっ たと考えられる。この点, 特異值分解法はデータ長に 依存しない，このため，時系列データの長さが異なる 場合でも，良い認識率を確保できていると考えられ る.

\section{4. 特異値を用いた動作認識}

次に, 動作認識として歩行動作を取り上げる。ただ し, ここでの歩行動作実験の目標は, 理学療法士およ び医師が患者の歩行回復の状態を推定するためとし， その目標のために患者の歩行困難度を数量化する。 そ こで, 被験者が患者の歩行を模擬するため, 被験者の 片脚の膝関節と足首関節を拘束し，関節可動域を制限 された状態で歩行計測を行う。計測装置として, マイ クロストーン(株)製の無線ウェアラブル 3 軸加速度セ
ンサー(MotionRecorder, MVP-RF8) とそのデータ処 理ソフトウェアを用いた。加速度センサーのサンプリ ングレートは $100 \mathrm{~Hz}$ であり, 前後方向 $(X$ 軸 $)$, 上下方 向 $(Y$ 軸), 左右方向 $(Z$ 軸 $)$ の 3 方向を同時に検出でき る.また, 拘束には, サンワサプライ(株)製の高齢者 疑似セットを用いた。歩行拘束のため, 被験者の右足 の膝に膝サポーターを装着し, 足首に重りバンドを装 着した。膝サポーターは被験者の関節可動域を減少さ せ膝の湾曲を困難にする。また, 重りバンドは被験者 の筋力の軽減と動作の遅延を発生させ, バランス感覚 を欠如させる。

これらの装置により, 被験者の歩行は患者の歩行と 類似する。実際に，これらの装置を装着した歩行動作 を医師に検分してもらった。医師からは「拘束条件が Strong の場合は，障害者の障害第 1 種 (関節可動域の 縮小)と類似しているが，しかし，WeakとNormalは， 視診からは鑑別できない。したがって，もしこれらの 拘束条件の違いがモデルにより判別できるならば， あ る意味では，医師の視診と同等の結果を得ることにな り，十分に研究の意義はある」とのコメントを得てい る.

図 6 に実験風景と拘束条件を示す。被験者は年齢 21 歳 31歳の男性 5 名 (YJ, TK, KT, KS, TF) と女性 1 名 (RT)の合計 6 名である。 $4 \mathrm{~m}$ の直進路での歩行を想 定し, 各被験者は 4 回の歩行を行う。歩行動作の加速 度を取得するため，3つの加速度センサーを装着した。 $P_{1}$ : 腰後方部 (B. Waist), $P_{2}$ : 右下腿部 (R. M. Shank),
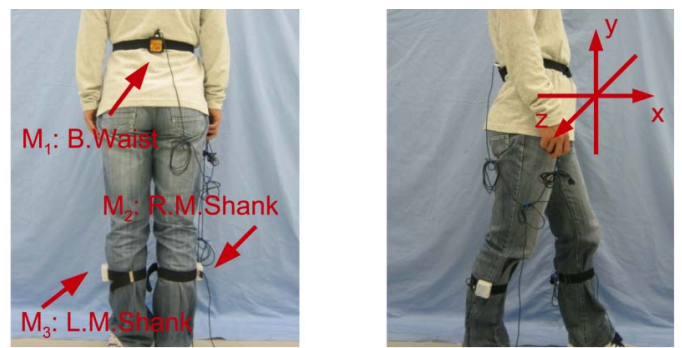

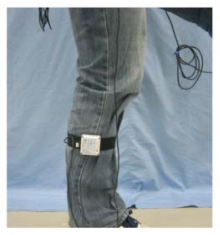

Normal

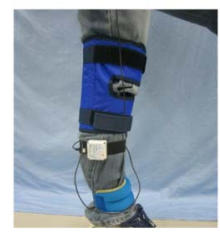

Weak

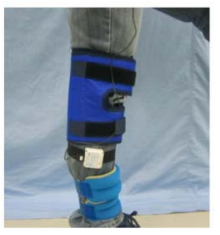

Strong
図 6 Experiment Environment for Ambulation 


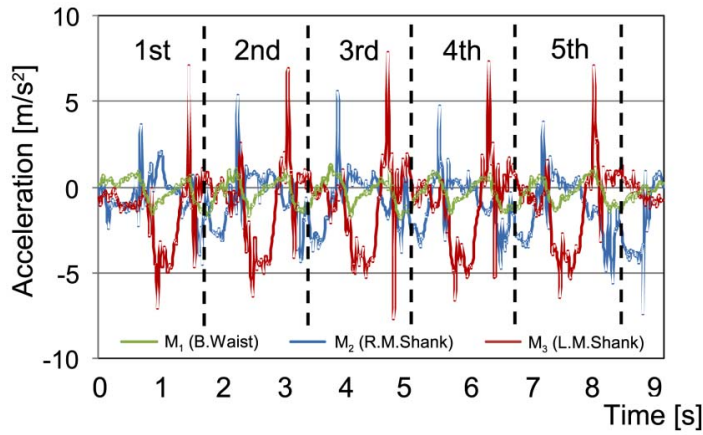

(a) Ambulation of Subject YJ

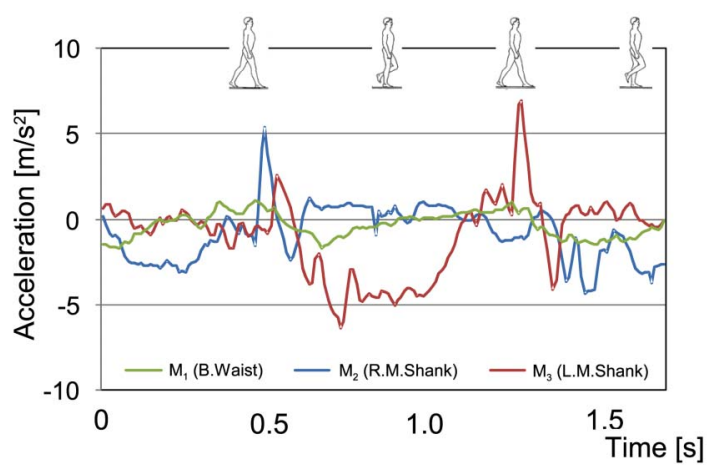

(b) Two Steps of Subject YJ

図 7 Example of Ambulation

$P_{3}$ : 左下腿部 (L. M. Shank)である。また, 歩行拘束 として, 正常歩行, 弱拘束歩行, 強拘束歩行の 3 種類 を設定し，弱拘束歩行では，1個の膝サポーターと $1 \mathrm{~kg}$ の重りを装着し, 強拘束歩行では, 2 個の膝サポー ターと $2 \mathrm{~kg}$ の重りを装着した。

被験者YJの弱拘束歩行での $X$ 軸方向の加速度変化 の時系列データを図 7 に示す。図 7 の (a) から, 被験 者YJは， $4 \mathrm{~m}$ の直進路を 5 歩調で歩行し, 歩行の際に 右足と左足の足踏み時に加速度変化が大きくなってい ることがわかる。また，この 5 歩調の時系列データの 1 歩調の時系列データを (b) に示す。右下腿部が拘束 されているので, $P_{2}$ の右下腿部の加速度変化が, $P_{3}$ の左下腿部より小さいことがわかる.

\section{1 特異値による歩行評価}

時系列データを抽出する際に, 時系列データの切り 出しの問題がある。動作の時系列データから特異值分 解で分析すべきデータ範囲を決定する問題である。い ま，観測された歩行動作の時系列データから，足踏み 時前後の加速度変化に特徴が出現していることがわ かった，そこで，ここでは，足踏み時の加速度変化に 注目してデータを抽出する。被験者は $4 \mathrm{~m}$ 歩行中で 4 歩〜 5 歩を要しており, 歩行開始と歩行終了に関与
しない中間歩行の 3 歩を切り出した. 足踏み時の加速 度の最大值の前後 0.5 秒間を抽出し, 加速度センサー のサンプリングレイトの $100 \mathrm{~Hz}$ から 100 個のデータを 抽出した。 また, 3 個の計測点 $P_{1}, P_{2}, P_{3}$ と 3 軸 $X$, $Y, Z$ から， 9 個のハンケル行列を構成した。これら の結果, データ個数と歩数の $100 \times 3$ からなる 9 種類 のハンケル行列が構成された。

特異值は, $l=1$ として, 9 個のハンヶル行列から 第 1 特異值を抽出し, 実験は 4 回行うので, 4 回の平 均值を計算した。右足の足踏み時の加速度の最大值を 基準としたハンケル行列から得られた被験者 6 名の第 1 特異值を表 6 に示す。 $P_{1}$ の腰後方部の特異值では 特徵的な変化は見られなかった。 歩行動作は腰を軸に して進むので, 通常, 腰は安定していることが予想さ れ，この結果は歩行の安定性を評価していると考えら れる。一方，個人に多少の差が認められるが， $P_{2}$ と $P_{3}$ の特異值は, 右足拘束の強さ (Normal, Strong, Weak) に依存して値が小さくなる傾向が示された。特に， $P_{2}$ では, $X, Y, Z$ 軸の 3 軸とも特異值が減少した。この $P_{2}$ は, 右下腿部の加速度を計測しているので, 拘束 の強さによって特異值が変化することは良く理解でき る。そこで, 今後, 拘束の程度による歩行困難性は $\mathrm{P}_{2}$ の特異值から同定することとした。

\section{2 歩行のリハビリテーション平面の抽出}

ここでは, 理学療法士および医師による患者の歩行 回復の状態推定をサポートするため, 歩行の困難性を 定量的に表現する手法を提案する。まず，各被験者の 歩行困難性を明示的に検討するため, 全被験者の右下 腿部 $P_{2}$ の拘束歩行の 4 回実験の特異值を $X, Y, Z$ の 3 次元上で表示した。結果を図 8 に示す。拘束歩行は 3 種類で 4 回の実験, 被験者が 6 名なので, 合計 72 個 のデータが表示されている。これらの各拘束歩行の 4 回の実験分の平均值を直線で結んだ。図 8 から, 平均 值の直線はある傾きをもち, 拘束歩行間のクラス識別 が可能と思われる.

そこで, 拘束歩行の級間変動と級内変動に基づく分 散分析を行った。 F 検定の結果を表 7 に示す。帰無仮 説として $\left\lceil H_{0}: 3\right.$ 種類の拘束歩行の特異值平均に差異 がない」を仮定し，対立仮説として $\left\lceil H_{1}: 3\right.$ 種類の拘 束歩行の特異值平均に差異がある」を仮定した。 $X, Y$, $Z$ の 3 軸方向の $P$ 值が，それぞれ，6.61E-11, 9.56E$14,6.93 \mathrm{E}-08$ となり, 有意水準 $5 \%$ よりも小さいの で, 帰無仮説 $\left\lceil H_{0}: 3\right.$ 種類の拘束歩行の特異值平均に 差異がない」を棄却し，3 種類の拘束歩行は特異值平 均に差異があると認められた。これらの結果から, 拘 束歩行ごとにクラス識別できることがわかる。この結 
表 6 Singular Value of Ambulation Experiment

\begin{tabular}{c|c|c|c|c|c|c|c|c|c|c}
\hline \multirow{3}{*}{ Subjects } & Restraint & \multicolumn{3}{|c|}{$P_{1}$} & \multicolumn{3}{c|}{$P_{2}$} & \multicolumn{3}{c}{$P_{3}$} \\
\cline { 3 - 10 } TF & Ambulation & $X$ & $Y$ & $Z$ & $X$ & $Y$ & $Z$ & $X$ & $Y$ & $Z$ \\
\hline \multirow{3}{*}{ YJ } & Normal & 17.7 & 23.4 & 21.8 & 57.9 & 52.7 & 50.9 & 46.8 & 55.6 & 33.4 \\
& Weak & 17.0 & 23.3 & 26.9 & 33.3 & 34.7 & 39.4 & 42.5 & 48.0 & 28.4 \\
& Strong & 17.6 & 22.8 & 27.3 & 31.7 & 30.3 & 37.7 & 40.4 & 43.1 & 27.8 \\
\hline \multirow{3}{*}{ TK } & Normal & 11.4 & 9.4 & 12.1 & 45.9 & 40.5 & 22.2 & 47.3 & 48.2 & 18.9 \\
& Weak & 10.9 & 8.2 & 15.4 & 23.4 & 11.2 & 13.9 & 43.9 & 33.5 & 14.7 \\
& Strong & 18.3 & 10.4 & 18.5 & 19.5 & 10.2 & 13.0 & 42.0 & 25.6 & 13.7 \\
\hline \multirow{3}{*}{ KS } & Normal & 18.1 & 19.3 & 12.6 & 51.1 & 34.3 & 34.0 & 51.9 & 47.8 & 30.1 \\
& Weak & 20.6 & 20.4 & 17.0 & 27.5 & 25.1 & 26.4 & 45.7 & 45.8 & 27.3 \\
& Strong & 20.2 & 20.0 & 15.7 & 25.3 & 20.1 & 21.9 & 42.8 & 38.5 & 27.7 \\
\hline \multirow{3}{*}{ RT } & Normal & 20.2 & 19.0 & 12.8 & 60.4 & 58.8 & 36.3 & 57.3 & 66.4 & 25.8 \\
& Weak & 19.7 & 15.8 & 19.0 & 36.8 & 32.0 & 21.5 & 52.4 & 55.0 & 20.1 \\
& Strong & 18.8 & 15.9 & 19.2 & 33.5 & 29.3 & 18.9 & 39.6 & 34.6 & 19.3 \\
\hline \multirow{3}{*}{ KT } & Normal & 28.0 & 24.5 & 19.6 & 70.8 & 53.7 & 37.5 & 58.7 & 58.0 & 32.5 \\
& Weak & 24.5 & 22.3 & 17.8 & 60.7 & 34.9 & 27.3 & 56.9 & 58.1 & 30.4 \\
& Strong & 22.5 & 23.7 & 19.1 & 51.5 & 33.3 & 20.8 & 50.3 & 52.7 & 26.1 \\
\hline \hline \multirow{3}{*}{ Ave. } & Normal & 23.4 & 27.5 & 17.9 & 57.1 & 65.3 & 40.3 & 60.6 & 74.3 & 32.0 \\
& Weak & 21.6 & 31.5 & 24.3 & 40.3 & 37.4 & 25.4 & 46.0 & 59.6 & 22.1 \\
& Strong & 18.5 & 24.3 & 22.4 & 38.5 & 26.8 & 16.0 & 38.5 & 46.4 & 16.4 \\
\hline & Normal & 19.8 & 20.5 & 16.1 & 57.2 & 50.9 & 36.9 & 53.8 & 58.4 & 28.8 \\
& Weak & 19.1 & 20.3 & 20.1 & 37.0 & 29.2 & 25.7 & 47.9 & 50.0 & 23.8 \\
& Strong & 19.3 & 19.5 & 20.4 & 33.3 & 25.0 & 21.4 & 42.3 & 40.2 & 21.8 \\
\hline
\end{tabular}

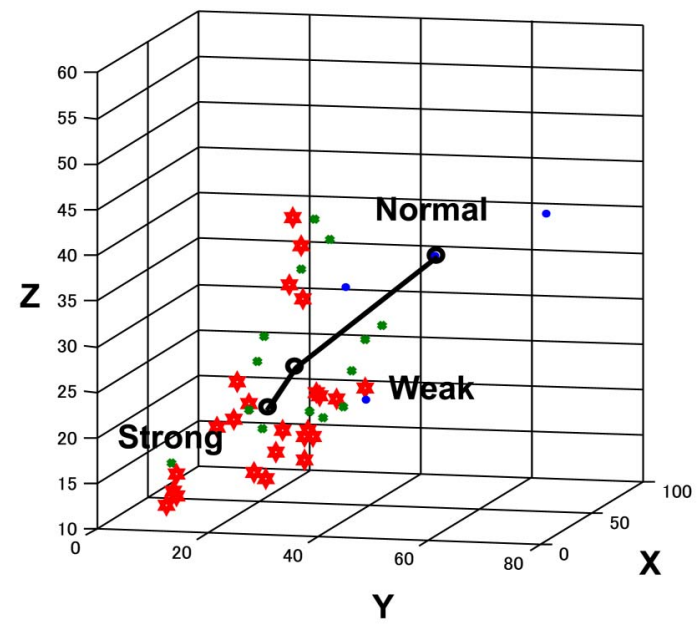

図 8 Singular Value of Ambulation Experiment

果を用いて, $X, Y, Z$ の 3 次元上で, 患者の歩行状態 を明示する手法を提案した。

いま, 特異值の平均值を含む超平面を構成し, この 平面内で, 被験者(患者)の歩行状態から平均值の直線 へ垂線を下ろす。その直線上の座標点によって, 被験 者(患者)の歩行状態を判別する. 平面を用いて患者の
表 7 Result of F Test on Restraint Ambulation

\begin{tabular}{c|c|ccccc}
\hline \multicolumn{2}{c|}{\begin{tabular}{c} 
Variation \\
\multicolumn{2}{c|}{ Factor }
\end{tabular}} & $\begin{array}{c}\text { Sum of } \\
\text { Sq. }\end{array}$ & df & $\begin{array}{c}\text { Mean } \\
\text { Sq. }\end{array}$ & $\begin{array}{c}\text { F } \\
\text { Val. }\end{array}$ & $\begin{array}{c}\text { Pal. } \\
\text { Xal. }\end{array}$ \\
\hline \multirow{3}{*}{ X } & Be.Gr. & 7902.4 & 2 & 3951.2 & 33.56 & $6.61 \mathrm{E}-11$ \\
& With.Gr. & 8123.9 & 69 & 117.7 & & \\
& Total & 16026.3 & 71 & & & \\
\hline \multirow{3}{*}{$\mathrm{Y}$} & Be.Gr. & 9263.1 & 2 & 4631.5 & 47.76 & $9.56 \mathrm{E}-14$ \\
& With.Gr. & 6690.9 & 69 & 97.0 & & \\
& Total & 15954.0 & 71 & & & \\
\hline \multirow{2}{*}{$\mathrm{Z}$} & Be.Gr. & 7902.4 & 2 & 1536.8 & 21.13 & $6.93 \mathrm{E}-08$ \\
& With.Gr. & 8123.9 & 69 & 72.7 & & \\
& Total & 16026.3 & 71 & & & \\
\hline
\end{tabular}

歩行回復(リハビリテーション)を推定するので, この 平面を $R$ 平面と呼ぶ. $R$ 平面の法線べクトルを $\vec{n}=$ $\left(n_{x}, n_{y}, n_{z}\right)$ で表し, 正常歩行の特異值の平均值の座 標を $\left(\sigma_{x}^{N}, \sigma_{y}^{N}, \sigma_{z}^{N}\right)$ で表すと, 平面 $R$ は次のように表 される。

$n_{x}\left(x-\sigma_{x}^{N}\right)+n_{y}\left(y-\sigma_{y}^{N}\right)+n_{z}\left(z-\sigma_{z}^{N}\right)=0$

$R$ 平面の概念図を図 9 に示す。被験者 $\mathrm{A}$ (患者 $\mathrm{A}) の$ 3 次元上での座標 $\left(\sigma_{x}, \sigma_{y}, \sigma_{z}\right)$ が $R$ 平面の座標 $\left(\sigma_{i}^{R}, \sigma_{j}^{R}\right)$ に投影され, 拘束歩行 (患者の歩行困難度)の平均值か らなる直線への座標点 $\left(\sigma_{i}^{*}, \sigma_{j}^{*}\right)=\left(\sigma_{x}^{*}, \sigma_{y}^{*}, \sigma_{z}^{*}\right)$ と各拘 束歩行 (患者の歩行困難度)の平均值への距離を求め 
る.この座標点と距離から, 被験者 $\mathrm{A}($ 患者 $\mathrm{A})$ の歩行 回復度を判別する。

いま，被験者TKを患者Aと仮定し，残りの 5 名の被 験者から作成した $R$ 平面を図10に示す， $R$ 平面は 5 名 の被験者から次のように得られた。

$-0.810 x+0.532 y+0.246 z+9.284=0$

被験者TK (患者A)の正常歩行, 弱拘束歩行, 強拘束 歩行は図上でそれぞれ，点 $(N L, W C, S C)$ と描かれ， 特異值の平均值からなる直線へは, 点 $\left(N L^{*}, W C^{*}, S C^{*}\right)$ として描かれている。正常歩行への識別が良いとは言 えないが，弱拘束歩行と強拘束歩行は正しく識別され ている。これらの結果から， $R$ 平面によって，歩行の 困難性が定量的に表現され, 患者の歩行回復の状態推 定を理学療法士および医師へ視覚的に提示できる.

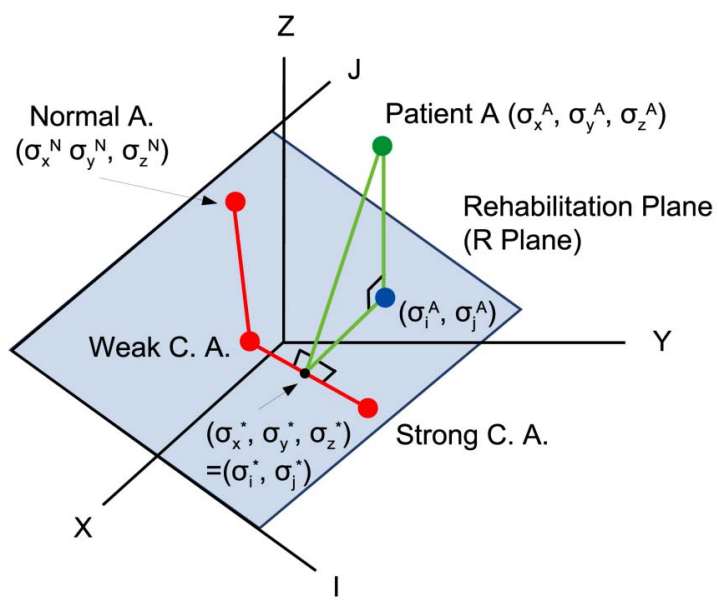

図 9 Rehabilitation Plane

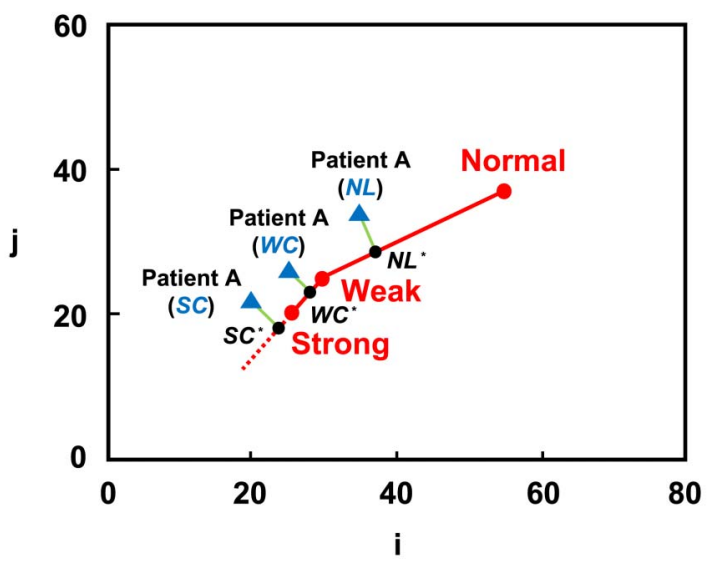

図10 Example of Rehabilitation Plane

\section{5. 考察}

本論文では, 特異值分解を用いて, 動作を計測した 時系列データから，その特徴を抽出する手法を提案し た。特異值分解でも, 特に, 左特異べクトルと特異值 が有用であるという観点から, それぞれの手法を提案 し，左特異ベクトルに関しては手招き動作を識別し， 特異值に関しては歩行動作を識別した。これらの手法 は, 特異值分解を用いているので，その認識精度は時 系列データの長さに依存しない。実際，左特異べク卜 ルを用いた動作距離法と動作べクトル法の 2 種類の判 別法では, 従来手法である相関係数の判別法や主成分 分析を用いた 2 種類の判別法よりも, その認識率が良 い. なお, 動作距離法も動作べクトル法も類似度 $S_{2}$ と評価 $E_{1}$ の組み合わせが最も良い結果を得た。類似 度 $S_{2}$ は左特異べクトルの要素の同順位の差の和の絶 対值から計算され, 評価 $E_{1}$ は各マーカで類似度が最 小となるジェスチャーを求め, 全マーカでのカウント 個数でジェスチャーの解を求めている。これらは, 左 特異ベクトルの順序がデータ特徴を良く表現している ことを示しており, また, ジェスチャ一動作の決定に は, マーカごとの多数決が効果的であることを示して いる，これは，ジェスチャ一動作の場合の手首や歩行 動作の腰椎部のように, 計測点によっては全ての動作 に共通の動きを示す箇所があり, 動作解析法では, 計 測点の加重平均よりも多数決の方が効果的であること を示唆している.この示唆は今後の研究課題としても 興味深い。

また, 各マーカのジェスチャー動作の認識結果か ら, 動作距離の類似性による手法も動作べクトルの類 似性による手法も, 右手の親指先端部の第 1 マーカ $P_{1}$ の認識率が $93.85 \%$ と高く, 最も重要なマーカとし て抽出されている(図11参照)。この理由の一つとし て, 親指が体の中心軸に近いこと, あるいは, 顔に近 いことが理由にあるのではないかと推測できる $[34$, 35]。ヒトは, ジェスチャ一動作を判別する際に, 体 の中心軸からの偏差として手の位置や速度, 回転等を 観測することで，そのジェスチャー動作の認識を高め ることができる。あるいは, ジェスチャ一動作の際 に, 親指がヒトを判別する際の重要因子の顔に近いこ とで, 親指の動作が自然と良く記憶している動作と考 えることもできる。しかしながら，これらの仮説はま だ推測の域を出ず，この検証は今後の課題としておき たい.

一方，特異值を用いた歩行動作の解析では，歩行に 拘束を科して実験を行い，その有用性を検討した。 3 点のみの計測であったが, 特異值の 3 次元計測の分散 


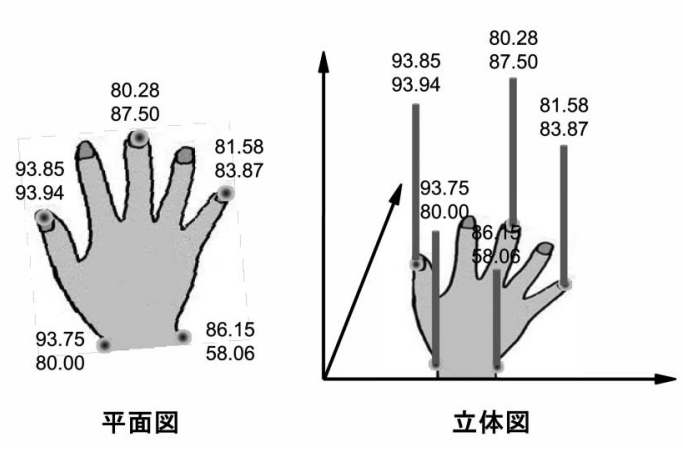

図 11 Recognition of Markers

分析から, 正常歩行, 弱拘束歩行, 強拘束歩行の 3 種 類のグループが有意的に識別できることを示した。特 に, 拘束を科した右足の特異值のみで拘束性を判別で きることを示したのは有用である。 また, 歩行の困難 性を定量的に表現する方法として $R$ 平面を定義した。 $R$ 平面により, 容易に被験者(患者)の歩行状態が推定 できる。したがって, この $R$ 平面は, 将来, 理学療 法士や医師が患者の歩行回復を判断する際のツールと して期待できる。ただ，今後，多くの被験者を用いて 実験を行い， $R$ 平面の有用性をさらに検討する必要が ある。

ここでは, 動作の入出力データから身体の内部モデ ルを得るための解析モデルの一例を示した. 我々が 日々行なっている動作は, 脳生理や身体構造的観点か ら見た場合, どのような諸機能によって成り立ってい るかは良くはわかっていない.しかし, ヒトは, 手招 き動作などの簡単な動作の学習に長い時間を必要とせ ず, また, 理学療法士や医師は患者の病理状態を一瞥 しただけで識別できる。これらのヒトの判断機能は, 脳生理学や身体構造学の知見を必要としなくても, そ の判断決定の構造化は可能である。ここで得られた知 識が身体知といえるには，まだ本モデルは完全ではな いが, 本手法のように入出力データから内部モデルを 同定する手法も存在してよいと考えられる.

\section{6. おわりに}

本論文では, 特異值分解を用いて動き計測の時系列 データから，その動きの特徴を獲得する手法を提案し た。事例として, 左特異べクトルを用いたジェス チャー認識と特異值を用いた歩行機能の評価を取り上 げた。ジェスチャー認識では, 従来手法との比較にお いて, 本手法の有用性が示された。 また, 歩行の困難 性評価では, 新たな $R$ 平面の活用法を提案した。今 後, さらなる多くの実験により, 本手法の有用性を検
討する必要がある。

な打, 本研究の一部は, 文部科学省私立大学戦略的 研究基盤形成支援事業「セキュアライフ創出のための 安全知循環ネットワークに関する研究」(2008年〜 2012年) と関西大学先端科学技術推進機構社会基盤情 報学応用研究グループ「社会基盤情報学に基づくメン テナンス技術開発」(2010年〜2012年)の助成を得た. また, 文部科学省科学研究助成金(基盤研究 $(B)$ ) 課題 番号21300212 および(基盤研究(A)) 課題番号20240058 の助成を得た。

\section{参 考 文 献}

[1] 古川康一, “スキルサイエンス”, 人工知能学会誌, Vol.19, No.3, pp.355-364 (2004).

[2] J.K.Aggarwal, and Q.Cai, "Human Motion Analysis: A Review," Computer Vision and Image Understanding, Vol.73, No.3, pp.428-440 (1999).

[ 3 ] A.Kendon, Gesture: Visible Action as Utterance, Cambridge University Press (2004).

[4] R.Bowden, "Learning Statistical Models of Human Motion, IEEE Workshop on Human Modelling, Analysis and Synthesis (CVPR2000), pp.10-17 (2000).

[ 5 ] K.Furukawa, S.Igarashi, K.Ueno, T.Ozaki, S.Morita, N.Tamagawa, T.Okuyama, and I.Kobayashi, "Modeling Human Skill in Bayesian Network," Electric Transaction of Articial Intelligence (ETAI), Linkoping University Electronic Press (2002).

［6］五十嵐創, 植野研, 尾崎知伸, 森田想平, 古川康一, “ベイジアンネットワークによるチェロ演奏スキルモ デリング”,電子情報通信学会技術研究報告, Vol.102, No.709, pp.1-6 (2003).

[ 7 ] R.Balasubramaniam, and M.T.Turvey, "Coordination Modes in the Multisegmental Dynamics of Hula Hooping," Biological Cybernetics, Vol.90, pp.176-190 (2004).

[ 8 ] S.Furuya, and H.Kinoshita, "Organization of the Upper Limb Movement for Piano Key-depression Differs between Expert Pianists and Novice Players," Experimental Brain Research, Vol.185, No.4, pp.581-593 (2008).

[ 9 ] S.Furuya, R.Osu, and H.Kinoshita, "Effective Utilization of Gravity During Arm Downswing in Keystroke by Expert pianists," Neuroscience, Vol.164, No.2, pp.822-831 (2009).

[10] M.Kawato, "Internal Models for Motor Control and Trajectory Planning." Current Opinion in Neurobiology, Vol.9, Vol.6, pp.718727 (1999).

[11] R.C.Miall, D.J.Weir, D.M.Wolpert, and J.F.Stein, "Is the cerebellum a Smith predictor?," Journal of Motor Behavior, Vol.25, pp.203216 (1993).

[12] D.B.Skillicorn, Understanding Complex Datasets: Data Mining with Matrix Decompositions, CRC press (2007).

[13] Y.Jiang, I.Hayashi, M.Hara, and S.Wang, "Three- dimensional Motion Analysis for Gesture Recognition Using Singular Value Decomposition," Proceedings of 
2010 IEEE International Conference on Information and Automation, pp.805-810 (2010).

[14] Yinlai Jiang, Shuoyu Wang, and I.Hayashi, "Classification Accuracy Enhancement for an fNIRS BrainComputer Interface Using Sigular Spectrum Transformation," ICIC Express Letters, Vol.4, No.6 (A), pp.2195-2199 (2010).

[15］林勲, 美銀来, 原正直, 王碩玉, “特異值分解による避 難命令動作からの知識発見”, 第26回ファジィシステ ムシンポジウム講演論文集, pp.824-829（2010）.

[16] I.Hayashi, Y.Jiang, and S.Wang, "Embodied Knowledge of Gesture Motion Acquired by Singular Spectrum Analysis," Proceedings of the First International Conference on Vulnerability and Risk Analysis and Management (ICVRAM2010) and the Fifth International Symposium on Uncertainty Modeling and Anavysis (ISUMA2010), pp.45-52 (2011).

[17] S.Mitra, and T.Acharya, "Gesture recognition: a survey," IEEE Transactions on Systems, Man, and Cybernetics, Part C, Vol.37, No.3, pp.311-324 (2007).

[18] Y.Iwai, K.Watanabe, Y.Yagi, and M.Yachida, "Gesture Recognition Using Colored Gloves," Proceedings of IEEE International Conference on Patter Recognition (ICPR96), Vol.A, pp.662-666 (1996).

[19] M.V.Lamar, M.S.Bhuiyan, and A.Iwata, "Hand Gesture Recognition Using T-CombNET: A New Neural Network Model," IEICE transactions on information and systems, Vol.E83- D, No.11, pp.1986-1995 (2000).

[20] T.E.Jerde, J.F.Soechting, and M.Flanders, "Biological Constraints Simplify the Recognition of Hand Shapes," IEEE Transactions on Biomedical Engineering, Vol.50, No.2, pp.265-269 (2003).

[21] R.Williamson, and B.J.Andrews, "Gait Event Detection for FES Using Accelerometers and Supervised Machine Learning," IEEE Transactions on Rehabilitation Engineering, Vol.8, No.3, pp.312-319 (2000).

[22] T.L.Jakobsen, M.Christensen, S.S.Christensen, M.Olsen, and T.Bandholm, "Reliability of Knee Joint Range of Motion and Circumference Measurements after Total Knee Arthroplasty: Does Tester Experience Matter?," Physiotherapy Research International, Vol.15, No.3, pp.126-134 (2010).

[23] H.I.Suk, B.K.Sin, and S.W.Lee, "Hand Gesture Recognition Based on Dynamic Bayesian Network Framework," Pattern Recognition, Vol.43, pp.30593072 (2010).

[24] C.Uras and A.Verri, "Hand gesture recognition from edge maps", Proceedings of International Workshop on Automatic Face and Gesture Recognition, pp.116121 (1995).
[25] Y.Fang, K.Wang, J.Cheng and H.Lu, "A Real-Time Hand Gesture Recognition Method," Proceedings of International Conference on Multimedia and Expo (ICME2007), pp.995-998 (2007).

[26] W.H.Wu, A.A.Bui, M.A.Batalin, D.Liu, and W.J.Kaiser, "Incremental Diagnosis Method for Intelligent Wearable Sensor Systems," IEEE Transactions on Information Technology in Biomedicine, Vol.11, No.5, pp.553-562 (2007).

[27] M.J.Mathie, A.C.Coster, N.H.Lovell, and B.G.Celler, "Accelerometry: Providing an Integrated, Practical Method for Long-term, Ambulatory Monitoring of Human Movement," Physiological Measurement, Vol.25, No.2, R1-20 (2004).

[28] H.Lau, and K.Tong, "The Reliability of Using Accelerometer and Gyroscope for Gait Event Identification on Persons with Dropped Foot," Gait and Posture, Vol.27, No.2, pp.248- 57 (2008).

[29] M.E.Wall, A.Rechtsteiner, and L.M.Rocha, "Singular Value Decomposition and Principal Component Analysis." in A Practical Approach to Microarray Data Analysis, D.P. Berrar, W. Dubitzky, and M.Granzow, eds. pp.91-109, Kluwer (2003).

[30] T.Ide, and K.Inoue, "Knowledge Discovery from Heterogeneous Dynamic Systems Using Change-point Correlations," Proceedings of 2005 SIAM International Conference on Data Mining (SDM05), pp.571-576 (2005).

[31] 三嶋賢一, 金田さやか, 中西弘明, 堀口由貴男, 椹木 哲夫, “特異值分解を用いた動作における個人間の類 似と差異の抽出”, 第53回自動制御連合講演会, pp.409410 (2009).

[32］伊理正夫, “線形代数汎論”, 朝倉書店 (2009).

[33］杉原正顯, 室田一雄, “線形計算の数理”, 岩波書店 (2009).

［34］原島博, “顔学への招待”, 岩波書店（1998）

[35］山根茂, 菅生康子, 松本有央, 岡田真人, “顔の持つ 多彩な情報の脳内表現と連想記憶モデル”, 電子情報 通信学会技術研究報告, Vol.103, No.452, pp.37-40 (2003)

$$
\text { （2011年 } 6 \text { 月14日 受付） }
$$$$
\text { (2011年12月26日 採録) }
$$

\author{
[問い合わせ先］ \\ 干 569-1095 大阪府高㭇市霊仙寺町2-1-1 \\ 関西大学 総合情報学部 \\ 林 勲
}

TEL : 072-690-2448

E-mail : ihaya@cbii.kutc.kansai-u.ac.jp 


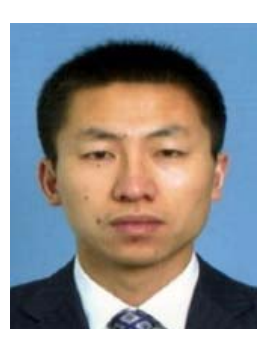

\section{姜 銀来 [正会員]}

2002 年中国東北大学情報工学専攻 卒業. 2005年同大学大学院修士課程 情報工学専攻修了。2008年高知工科 大学大学院博士後期課程基盤工学専攻 修了。同年高知工科大学助教, 現在に 至る. 博士 (工学). 動作解析, ヒュー マン・ロボット・インタラクション (HRI), 視覚認知の研究に従事. IEEE, 日本知能情報ファジィ学会, 日本ロ ボット学会, 日本生体医工学会の会員.

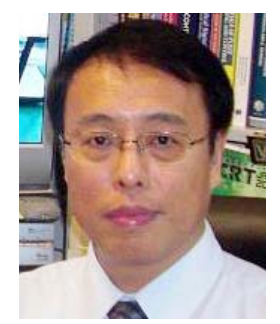

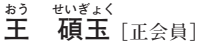

1983年中国瀋陽工業大学自動制御 工学専攻卒業. 1988年同大学院修士 課程自動制御工学専攻修了。1993年 北海道大学大学院博士後期課程電気工 学専攻修了. 同年, 山形大学工学部助 手. 1996年同大学助教授. 1997年高 知工科大学工学部助教授. 2001年同 大学教授, 現在に至る. 博士 (工学). ファジィ推論, ロボット制御, リハビ リテーションロボット, 生活支援ロ ボットなどの研究に従事. 日本機械学 会, 日本知能情報ファジィ学会, ライ フサポート学会, 日本ロボット学会, 日本生体医工学会, バイオメデカル. ファジィシステム学会, IFSA等の会 員.

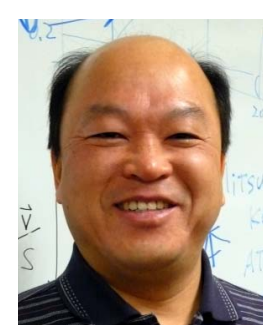

はやし いさ林 勲 [正会員]

1981年大阪府立大学工学部経営工 学科卒業後, シャープ(株) 入社. 1985 年大阪府立大学大学院工学研究科経営 工学専攻博士前期課程修了。松下電器 産業(株) (現パナソニック(株)) 中央研 究所を経て, 1993年阪南大学商学部 経営情報学科講師, 1997年経営情報 学部教授, 1997年南オーストラリア 州立大学KES招聘研究員, 1999年米 国ボストン大学大学院CNS招聘研究 員. 2010年米国ボストン大学大学院 CNS招聘教授. 2004年より関西大学 総合情報学部総合情報学科教授. 現在 に至る。神経回路モデルを用いた視覚 モデル, ファジィインタフェースによ る脳とロボットとの相互結合モデルの 研究に従事. 工学博士. 米国電気電子 学会 (IEEE), 日本知能情報ファジィ 学会, 日本神経回路学会, 日本視覚学 会, 日本基礎心理学会, システム制御 情報学会等の会員. 


\section{Acquisition of Motion Features by Singular Value Decomposition \\ by}

\section{Yinlai JIANG, Isao HAYASHI and Shuoyu WANG}

\section{Abstract :}

Recently, various methods that analysed physical movement have been proposed. Kawato has argued that internal model with closed loop between feedback control and feedforward control is useful for sinuous movement as a model for motor control. In this paper, we consider internal model as a function model identified from observed data, and propose a model to extract the characteristic of human movement with singular value decomposition from the time-series data of various sensors. We call the knowledge acquired by the internal model embodied knowledge. In particular, we categorized gesture motions by two kinds of models with the indexes of similarity and estimation using left singular vectors. In addition, the ambulation movement is distinguished by hyperplane of three-dimension constructed by singular value. Finally we discussed characteristic and significance of the movement analysis using singular value decomposition proposed in this paper.

Keywords : Singular Value Decomposition, Embodied Knowledge, Gesture Motion, Ambulatory Motion, Motion Analysis

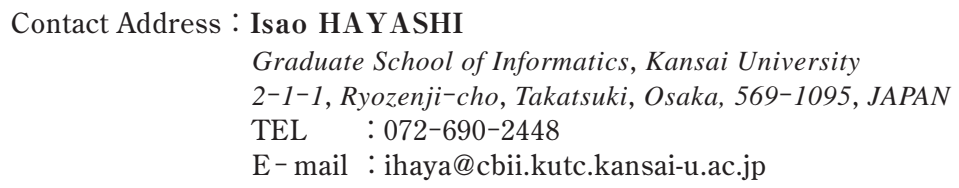

